\title{
EFEKTIFITAS MODEL PEMBELAJARAN GROUP INVESTIGASI DALAM MENINGKATKAN HASIL BELAJAR PKn SISWA KELAS IX-7 SMP NEGERI 1 BANGUN PURBA
}

\author{
Juriah Purba \\ Guru Mata Pelajaran PKn SMP Negeri 1 Bangun Purba \\ Surel : juriah.purba@yahoo.co.id
}

\begin{abstract}
Abstrak
Penelitian ini bertujuan untuk meningkatkan hasil belajara siswa dengan menerapkan model pembelajaran Group Investigasi. Berdasarkan tes hasil belajar (Pretes) diperoleh nilai rata-rata 60 dan ketuntasan 14,3\%. Kemudian dilanjutkan KBM. Akhir KBM ke II dan KBM ke IV dilakukan tes hasil belajar siswa pada siklus I rata-rata nilai tes 73,1 dengan ketuntasan pembelajaran sebesar $51,3 \%$ dan pada Siklus II rata-rata nilai tes 81,7 dengan ketuntasan pembelajaran naik menjadi $85,3 \%$. Perbandingan antara siklus I dan Siklus II dijabarkan, aktivitita s Siklus I antara lain menulis dan membaca (42\%), bekerja (27\%), bertanya sesama teman $5,3 \%)$, bertanya kepada guru $(14,2 \%)$, dan yang tidak relevan dengan KBM (12\%). (b) Data aktivitas siswa menurut pengamatan pada Siklus II antara lain menulis dan membaca $(25,6 \%)$, bekerja $(52,5 \%)$, bertanya sesama teman $(14,4 \%)$, bertanya kepada guru (3\%), dan yang tidak relevan dengan KBM $(4,4 \%)$.
\end{abstract}

Kata Kunci : Model Group Investasi, Hasil Belajar

\section{PENDAHULUAN}

Pendidikan berperanan penting dalam membina kehidupan bermasyarakat menuju masa depan yang lebih baik. Hal ini disebabkan karena pendidikan merupakan suatu upaya untuk meningkatkan kualitas setiap hidup individu baik secara langsung maupun tidak langsung dalam mengikuti laju perkembangan ilmu pengetahuan dan teknologi. Pendidikan merupakan usaha untuk membina dan mengembangkan potensi sumber daya manusia melalui kegiatan belajar mengajar yang diselenggarakan pada semua tingkat pendidikan baik dari tingkat dasar, menengah, dan perguruan tinggi. Pendidikan di sekolah harus mampu mengubah siswa menjadi seseorang yang berpengetahuan dan terampil. Agar tujuan pendidikan bisa tercapai dan maksimal tentunya guru sebagai pendidik akan terus menerus di tuntut untuk selalu mengembangkan model dan strategi pembelajarannya agar segala kesulitan dalam pembelajaran dapat dipecahkan yaitu meningkatkan hasil belajar siswa. Guru dengan sadar merencanakan kegiatan pengajarannya secara sistematis dengan memanfaatkan segala sesuatunya guna kepentingan pengajaran. Pada dasarnya semua guru menginginkan kompetensi tercapai dalam setiap pembelajaran. Salah satu masalah yang 
menyebabkan hasil belajar PKn siswa rendah disebabkan oleh kemampuan siswa yang beragam, juga disebabkan oleh variasi guru dalam mengajar, dimana guru memberikan pengajaran secara umum (konvensional) dan bersifat satu arah, guru berceramah, melakukan tanya jawab dan pemberian tugas tapi yang ditemukan siswa hanya duduk, mencatat, dan mendengarkan apa yang disampaikan guru, yang mengakibatkan siswa cenderung manjadi pasif, sehingga siswa beranggapan bahwa PKn merupakan mata pelajaran yang tidak menyenangkan sehingga siswa kurang mampu memahaminya.

Perubahan paradigma

pembelajaran saat ini lebih mempertimbangkan siswa dalam pembelajaran. Siswa bukanlah sebuah botol kosong yang bisa diisi dengan muatan-muatan informasi apa saja yang dianggap perlu oleh guru. Selain itu, alur proses belajar tidak harus berasal dari guru menuju siswa. Siswa bisa juga saling mengajar dengan sesama siswa yang lainnnya. Bahkan telah banyak hasil penelitian mengungkapkan bahwa pembelajaran kooperatif lebih unggul dalam mengupayakan pencapaian kompetensi dibandingkan pembelajaran konvensional dengan ceramah sebagai metode utamanya.

Upaya melaksanakan

pembelajaran berorientasi aktivitas terus dilakukan peneliti sebagai guru PKn di SMP Negeri 1 Bangun Purba. Beberapa variasi model pembelajaran kooperatif telah diterapkan. Bahkan sekolah telah menjadikan pembelajaran kooperatif sebagai pokok model pembelajaran yang diterapkan dalam kelas, untuk menyikapi perubahan paradigma ke arah pembelajaran berpusat pada siswa. Namun kendala yang harus dihadapi guru dalam menerapkan model pembelajaran kooperatif terus bermunculan. Pembelajarn kooperatif yang diterapkan guru seringkali memunculkan berbagai sikap negatif. Jika kerja kelompok tidak berhasil, siswa cenderung saling menyalahkan. Sebaliknya jika berhasil, muncul perasaan tidak adil. Siswa yang pandai/rajin merasa rekannya yang kurang mampu telah membonceng pada hasil kerja mereka. Semangat siswa dalam mengembangkan diri secara individual bisa terancam karena siswa bukannya belajar secara maksimal, melainkan belajar mendominasi ataupun melempar tanggung jawab. Akhirnya pembelajaran seperti ini berujung pada munculnya keributan di dalam kelas. Muncul pemikiran guru yang keliru bahwa melaksanakan pembelajaran kooperatif menyulitkan pengendalian kelas dan menyusahkan.

Pemikiran semacam ini mengakibatkan guru lebih memilih menerapkan pembelajaran konvensional yang berlangsunng satu arah karena dianggap lebih mudah dan menjamin siswa lebih terkendali dalam pembelajaran. Padahal hasil yang diperoleh sama buruknya, aktivitas belajar siswa tidak tergarap 
dengan baik. Dampaknya adalah hasil belajar PKn siswa tidak tercapai. Apalagi dampak pengiring pembelajaran PKn berupa keterampilan berpikir masih jauh dari harapan.

Berbagai dampak negatif dalam menggunakan pembelajaran kooperatif seharusnya bisa dihindari jika saja guru mau meluangkan lebih banyak waktu dan perhatian dalam mempersiapkan dan menyusun pembelajaran kooperatif. Yang diperkanalkan dalam pembelajaran kooperatif bukan sekedar kerja kelompok, melainkan pada penstrukturannya. Yang termasuk di dalam struktur ini adalah lima unsur pokok yaitu saling ketergantungan positif, tanggung jawab individual, interaksi personal, keahlian bekerja sama, dan proses kelompok.

Sebagai

mengembangakan peneliti dalam menerapkan pembelajaran kooperatif dan penguasaan teori belajarnya ditengah upaya memperbaiki aktivitas belajar PKn siswa maka desin yang paling tepat adalah menerapkan pembelajaran kooperatif dalam penelitian tindakan kelas. Karena dengan penelitian tindakan kelas akan dapat dianalisis kelemahan, kesesuaian, dan kelebihan peneliti dalam menerapkan pembelajaran kooperatif. Salah satu tipe yang memadai dari model pembelajaran kooperatif adalah Group investigation atau yang biasa disebut dengan GI. Pada model pembelajaran GI, guru menyiapkan terlebih dahulu masalah untuk sekelompok siswa pada jenjang kemampuan tertentu. Siswa menghadapi masalah yang kemudian diarahkan kepada menemukan konsep atau prinsip. Karena siswa secara bersama-sama menemukan konsep atau prinsip, maka diharapkan konsep tersebut tertanam dengan baik pada diri siswa yang pada akhirnya siswa menguasai konsep atau prinsip yang baik pula. Sehingga keterlibatan aktif siswa dalam proses pembelajaran dapat di tangani dengan baik.

$\begin{array}{rr}\text { Untuk } & \text { kepentingan } \\ \text { penyelidikan dalam } & \text { proses }\end{array}$ pembelajaran, maka penerapan model selayaknya didampingi oleh perangkat pembelajaran yang memadai pula. Salah satu perangkat pembelajaran yang mendukung terarahnya aktivitas belajar siswa dan membantu proses penemuan konsep adalah lembar kerja siswa (LKS). Sehingga dalam penelitian ini akan digunakan LKS untuk megoptimalkan penerapan model pembelajaran dalam kelas. Berdasarkan latar belakang masalah yang telah diuraikan dapat diidentifikasi permasalahan yang relevan terhadap pembelajaran PKn di SMP Negeri 1 Bangun Purba diantaranya : (1) Pembelajaran belum mengupayakan penanganan aktivitas belajar siswa dengan baik. (2) Pembelajaran kooperatif sering memunculkan sikap negatif saling melempar tanggung jawab atau mendominasi kelompok. (3) Guru memandang secara keliru bahwa pembelajaran kooperatif 
menyusahkan sehingga lebih memilih pembelajaran konvensional. (4) Keterbatasan pemahaman guru dalam menerapkan model pembelajaran kooperatif secara praktis. Berdasar indentifikasi masalah ini, maka rumusan masalah yaitu : (1) Apakah penerapan model pembelajaran kooperatif tipe Group investigation dapat meningkatkan hasil belajar siswa pada materi dampak globalisasi dalam kehidupan bermasyarakat, berbangsa, dan bernegara di kelas IX-7 SMP Negeri 1 Bangun Purba? (2) Apakah penerapan model pembelajaran kooperatif tipe Group investigation dapat meningkatkan aktivitas belajar siswa pada materi pokok dampak globalisasi dalam kehidupan bermasyarakat, berbangsa, dan bernegara di kelas IX-7 SMP Negeri 1 Bangun Purba?

Adapun tujuan penelitian, yaitu : (1) Untuk megetahui apakah penerapan model pembelajaran kooperatif tipe Group investigation dapat meningkatkan hasil belajar siswa pada materi pokok dampak globalisasi dalam kehidupan bermasyarakat, berbangsa, dan bernegara di kelas IX-7 SMP Negeri 1 Bangun Purba. (2) Untuk mengetahui apakah penerapan model pembelajaran kooperatif tipe Group investigation dapat meningkatkan aktivitas belajar siswa pada materi pokok dampak globalisasi dalam kehidupan bermasyarakat, berbangsa, dan bernegara di kelas IX-7 SMP Negeri 1 Bangun Purba.

\section{METODOLOGI PENELITIAN}

Penelitian ini akan dilaksanakan SMP Negeri 1 Bangun Purba yang beralamat di Jalan SM. Raja Kecamatan Bangun Purba.. Penelitian ini dilaksanakan pada semester genap Tahun Pelajaran 2014/2015 selama 6 (bulan) bulan mulai dari bulan Februari sampai dengan Juli 2015. Pengambilan data dilaksanakan selama 4 (empat) KBM yang dibagi dalam 2 (dua) Siklus. Subjek penelitian ini adalah siswa kelas IX-7 SMP Negeri 1 Bangun Purba yang berjumlah 35 siswa. Penelitian ini berbentuk Penelitian Tindakan Kelas (PTK). Penelitian tindakan kelas adalah penelitian yang dilakukan oleh guru di kelas atau di sekolah dengan penekanan pada penyempurnaan atau peningkatan proses pembelajaran. Dalam satu siklus terdiri atas empat langkah, yaitu perencanaan (planning), tindakan (acting), observasi (observing) dan refleksi (reflecting).

\section{HASIL PENELITIAN DAN PEMBAHASAN}

Kondisi awal sisa kelas IX-7 yang menyangkut hasil belajar PKn maka dilakukan tes kemampuan awal siswa sebelum Siklus I dilaksanakan sebagai Pretes untuk mengetahui kemampuyan awal siswa. Dari hasil tes diperoleh nilai terendah 50 dan tertinggi 80 dengan rata-rata 60 dan KKM 75 sehingga ketuntasan belajar secara kalsikal $14,3 \%$. Atau kemampuan awal siswa 
sangat rendah mengindikasikan bahwa siswa tidak membaca buku di rumah untuk materi yang akan dipelajari di sekolah.

\section{Hasil Penelitian Siklus I}

Setelah berakhirnya pelaksanaan Siklus I diadakan tes hasil belajar siswa yang sebagai formatif I. Hasil belajar siswa yang diperoleh pada siklus I selama dua pertemuan disajikan dalam Tabel 1.

Tabel 1 Deskripsi Data Formatif I

\begin{tabular}{|c|c|c|}
\hline Nilai & Frekuensi & Rata-rata \\
\hline 60 & 17 & \\
\cline { 1 - 2 } 80 & 13 & \multirow{2}{*}{73,1} \\
\cline { 1 - 2 } 100 & 5 & \\
\cline { 1 - 2 } Jumlah & 35 & \\
\hline
\end{tabular}

Dari tabel 1 Siswa dengan nilai terendah (50) sebanyak 17 siswa dan yang mendapat nilai tertinggi ( 100 ) sebanyak 5 siswa. nilai rata-rata 73,1 dengan KKM 75 jumlah siswa tuntas 18. Hasil tersebut menunjukkan bahwa pada Siklus I secara klasikal siswa belum tuntas belajar, dengan rata-rata kelas mencapai 73,1 karena siswa yang memahami materi yang telah disampaikan hanya sebesar $51,3 \%$ lebih kecil dari persentase ketuntasan yang dikehendaki yaitu sebesar $85 \%$. Hal ini disebabkan karena siswa masih merasa baru dan belum mengerti apa yang dimaksudkan dan digunakan guru dengan menerapkan model pembelajaran koperatif tipe group investigation.
Kemudian didalam KBM ke I dan KBM ke II dilakukan pengamatan oleh dua orang pengamat dibantu menggunakan lembar observasi aktivitas dilakukan pada saat siswa bekerja dalam kelompok diskusi. Pengamatan dilakukan oleh dua pengamat selama 20 menit kerja kelompok dalam setiap kegiatan belajar mengajar (KBM). Hasil observasi aktivitas siswa disajikan dalam tabel 2.

Tabel 2. Skor Aktivitas Belajar Siswa Siklus I

\begin{tabular}{|c|c|c|c|}
\hline No & Aktivitas & Skor & Proporsi \\
\hline 1 & Menulis dan membaca & 20 & $42 \%$ \\
\hline 2 & Mengerjakan LKS & 12,75 & $27 \%$ \\
\hline 3 & Bertanya pada teman & 2,5 & $5,3 \%$ \\
\hline 4 & Bertanya pada guru & 6,75 & $14,2 \%$ \\
\hline 5 & Yang tidak relevan & 47,5 & $12 \%$ \\
\hline & Jumlah & 50 & $100 \%$ \\
\hline
\end{tabular}

Merujuk pada Tabel 2. aktivitas dominan yang dilakukan siswa adalah menulis dan membaca (42\%) kondisi ini belum sesuai dengan yang diharapkan karena seharusnya aktivitas mengerjakan LKS lebih dominan ketimbang aktivitas individual tersebut, sementara aktivitas bekerja dalam diskusi(mengerjakan LKS) dalam posisi kedua (27\%), bertanya pada guru $14,2 \%$ atau siswa masih sangat bergantung pada guru. Dan aktivitas bertanya pada teman dan yang tidak relevan berturut-turut $5,3 \%$ dan $12 \%$. Hal ini disebabkan karena siswa masih merasa baru dan belum mengerti apa yang dimaksudkan dan digunakan guru dengan menerapkan 
model pembelajaran koperatif tipe group investigation. Dengan demikian maka peneliti berusaha melakukan tindakan perbaikan dalam melaksanakan pembelajaran Siklus II yang dirasa perlu.

\section{Hasil Penelitian Siklus II}

Diakhir Siklus II diberikan tes hasil belajar sebagai Formatif II dengan jumlah soal 5 item. Data Formatif II disajikan dalam Tabel 3.

Tabel 3 Deskripsi Data Formatif II

\begin{tabular}{|c|c|c|}
\hline Nilai & Frekuensi & Rata-rata \\
\hline 60 & 5 & \\
\cline { 1 - 2 } 80 & 22 & \multirow{2}{*}{81.7} \\
\cline { 1 - 2 } 100 & 8 & \\
\cline { 1 - 2 } Jumlah & 35 & \\
\hline
\end{tabular}

Merujuk pada Tabel 3, siswa dengan nilai terendah (60) sebanyak 5 siswa dan yang mendapat nilai tertinggi (100) sebanyak 8 orang. nilai rata-rata 81,7 dengan jumlah siswa tuntas 30. Hal ini menunjukkan siswa mulai memahami penjelasan guru. Hasil tersebut menunjukkan bahwa pada Siklus II secara klasikal siswa sudah tuntas belajar, karena siswa yang memahami materi yang telah disampaikan sebesar $85,3 \%$ mencapai persentase ketuntasan yang dikehendaki yaitu sebesar $85 \%$. Hal ini disebabkan karena siswa sudah mulai beradaptasi dengan apa yang dimaksudkan dan digunakan guru dengan menerapkan model pembelajaran kooperatif tipe group investigation.
Tabel 4. Skor Aktivitas Belajar Siswa Siklus II

\begin{tabular}{|c|l|c|c|}
\hline No & \multicolumn{1}{|c|}{ Aktivitas } & Skor & Proporsi \\
\hline 1 & $\begin{array}{l}\text { Menulis dan } \\
\text { Membaca }\end{array}$ & 10,25 & $25,6 \%$ \\
\hline 2 & Mengerjakan LKS & 22 & $52,5 \%$ \\
\hline 3 & $\begin{array}{l}\text { Bertanya pada } \\
\text { teman }\end{array}$ & 5,75 & $14,4 \%$ \\
\hline 4 & Bertanya pada guru & 1,25 & $3 \%$ \\
\hline 5 & Yang tidak relevan & 1,75 & $4,4 \%$ \\
\hline \multicolumn{2}{|c|}{ Jumlah } & 40 & $100 \%$ \\
\hline
\end{tabular}

Merujuk pada Tabel 4 aktivitas menulis dan membaca $(25,6 \%)$ kondisi ini menuju kearah yang diharapkan karena memang seharusnya aktivitas diskusi (mengerjakan LKS) lebih dominan ketimbang aktivitas individual tersebut dengan proporsi $(52,5 \%)$, bertanya pada guru turun mencapi $3 \%$ atau siswa mulai tidak bergantung pada guru. Dan aktivitas bertanya pada teman dan yang tidak relevan berturut-turut $14,4 \%$ dan $4,4 \%$. Membaikanya pengelolaan pembelajaran oleh guru dan aktivitas belajar siswa berdampak pula pada peningkatan hasil belajar siswa di akhir Siklus II. Hal itu menyebabkan ada peningkatan pada hasil belajar.

\section{Pembahasan}

Pembahasan terhadap permasalahan penelitian tindakan berdasarkan analisis data kualitatif hasil penelitian dari kerja kolaborasi antara peneliti, guru sejawat, 
narasumber dan pembimbing penelitian yang terlibat dalam kegiatan ini, sebelum dan sesudah penelitian yang dibuat oleh guru yang melakukan tindakan kerja kolaborasi dimulai: 1) dialog awal, 2) perencanaan tindakan yaitu identifikasi masalah yang diduga mempengaruhi hasil belajar siswa dan penyebabnya; perencanan solusi masalah, 3) pelaksanaan tindakan, dan 4) evaluasi hasil pelaksanaan tindakan.

Merujuk pada tabel 1 dan tabel 3. Data kemampuan awal menunjukan tidak seorang siswapun mendapat nilai diatas KKM sehingga ketuntasan $14,2 \%$ dengan rata-rata 60. Pada Formatif I menunjukkan, 30 dari 35 siswa tidak memenuhi kriteria ketuntasan minimal (KKM) sebesar 80, siswa yang telah tuntas sebanyak 18 siswa atau $51,3 \%$. Sehingga pembelajaran Siklus I dikatakan gagal memberi ketuntasan secara klasikal karena kurang dari 85 $\%$.

Kendala pada Siklus I yang ditindaklanjuti di Siklus II telah menunjukkan peningkatan yang berarti dalam perolehan skor. Hal ini nampak pada perolehan data pada Gambar 4, dimana siswa yang tuntas mengalami kenaikan, dari 18 siswa di Siklus I menjadi 30 siswa yang tuntas di Siklus II, jadi sekitar 85,3\% telah tuntas. Karena ketuntasan klasikal telah melampaui $85 \%$ maka KBM Siklus II dikatakan berhasil meningkatkan hasil belajar siswa samapai pada ketuntasan klasikal yang diharapkan. Dengan demikkian penguasan pembelajarn PKN siswa telah meningkat selama dua siklus penelitian.

Peningkatan hasil belajar sehingga tuntas klasikal pada Siklus II ini diperoleh dari tindakan perbaikan pada Siklus II diantaranya:

a. Pembelajaran diskusi lebih di tekankan, diberikan lebih banyak kesempatan siswa melaksanakan bagian ini dari pada bagian lain.

b. Mendesain LKS pada bagian analisis dengan kalimat dan teknik yang lebih memudahkan siswa mencapai pada kesimpulan.

c. Pembimbingan pada masingmasing kelompok dibatasi oleh waktu yang telah ditetapkan merata untuk semua kelompok.

d. Guru menganalisis kembali kemampuan penerapan model dan materi ajar dengan memperkirakan kesulitankesulitan yang akan dihadapi siswa dan jalan keluar langsung yang dapat ditempuh ditengah KBM berlangsung.

Perbaikan kualitas proses dan hasil belajar diperkuat dengan dokumentasi penelitian pada lampiran dan data aktivitas belajar siswa yang merujuk pada Tabel 2 . Dan Tabel 4 menunjukkan peningkatan kualitas pada aktivitas belajarnya dari Siklus I ke Siklus II. Aktivitas kerja naik dari 27\% menjadi 52,5\%, kondisi ini sudah lebih baik dan menuju yang diharapkan karena seharusnya 
aktivitas diskusi atau kerja lebih dominan, sementara aktivitas menulis dan membaca dalam posisi kedua (42\%) dan masih cukup tinggi meskipun sudah turun dari Siklus I ( $25,6 \%$ ), bertanya pada guru dari $14,2 \%$ menjadi $3 \%$ menunjukkan ketergantungan pada guru sudah menurun walupun hanya sedikit. Dan aktivitas bertanya pada teman naik dari $5,3 \%$ menjadi $14,4 \%$, hal ini terlihat dari ada kedekatan yang terjalin antara siswa, yakni pada saat siswa sedang berkoordinasi mengenai hal-hal yang perlu diperbaiki saat mereka berdiskusi kelompok. Sedangkan aktivitas yang tidak relevan turun sedikit dari $12 \%$ menjadi 4,4\%. Sehingga terjadi perbaikan aktivitas belajar selama dua siklus penelitian.

Secara

keseluruhan

pelaksanaan proses pembelajaran yang dilakukan oleh peneliti sudah sesuai dengan harapan, karena sudah menggunakan model pembelajaran kooperatif tipe group investigation dengan baik dan benar. Sehingga siswa memiliki minat dalam belajar berkaitan dengan tindak mengajar yang dilakukan peneliti sebagai guru di kelas adalah selalu memberikan tujuan pembelajaran, membimbing dan mengarahkan siswa yang bertujuan menciptakan hubungan baik dengan siswa, mendorong dan membimbing siswa dalam menyampaikan ide, berlaku adil pada semua siswa, mengingatkan siswa untuk mengulangi materi yang telah diajarkan, memberi semangat siswa dalam belajar, menciptakan suasana yang membuat siswa terlibat secara aktif dan memberi latihan soal-soal.

Proses pembelajaran yang dilakukan dengan gaya mengajar terbuka merupakan upaya pembenahan gaya mengajar guru. Pembenahan yang diupayakan antara lain model pembelajaran klasikal, yang cenderung dilaksanakan tanpa variasi dibenahi menjadi model pembelajaran kooperatif tipe group investigation. Pembenahan ini dilaksanakan dengan strategi pembelajaran terbuka, yaitu menjamin rasa aman, nyaman dan senang dalam pembelajarannya serta guru selalu menarik dan memelihara minat belajar siswa.

Beberapa tindak mengajar tersebut merupakan tindakan guru yang merupakan kunci keberhasilan atau memberikan hasil yang memuaskan dan dipandang memberikan kontribusi yang cukup bagi keberhasilan usaha meningkatkan hasil belajar.

Melalui model pembelajaran kooperatif tipe GI dengan penyampaian materi melalui diskusi sehingga siswa berpikir induksi, perencanaan pembelajaran ini dapat dilaksanakan dengan baik. Hal itu ditunjukkan oleh hasil evaluasi pelaksanaan tindakan kelas yang dilaporkan terdahulu. Tindakan belajar dan mengajar seperti telah dilaporkan pada evaluasi tindakan kelas, tindakan-tindakan guru tersebut memenuhi teori dalam menciptakan kondisi belajar yang kreatif. 
SIMPULAN DAN SARAN

Dari hasil kegiatan

pembelajaran yang telah dilakukan selama dua siklus, dan berdasarkan seluruh pembahasan serta analisis yang telah dilakukan dapat disimpulkan penerapan model pembelajaran kooperatif tipe group investigation pada pembelajaran PKn di kelas IX-7 SMP Negerei 1 Bangun Purba Tahun Pelajaran 2014/2015 sebagai berikut:

a. (a) Data aktivitas siswa menurut pengamatan pengamat pada Siklus I antara lain menulis dan membaca (42\%), bekerja (27\%), bertanya sesama teman $(5,3 \%)$, bertanya kepada guru $(14,2 \%)$, dan yang tidak relevan dengan KBM (12\%). (b) Data aktivitas siswa menurut pengamatan pada Siklus II antara lain menulis dan membaca $(25,6 \%)$, bekerja $(52,5 \%)$, bertanya sesama teman $(14,4 \%)$, bertanya kepada guru (3\%), dan yang tidak relevan dengan KBM $(4,4 \%)$. Sehingga pembelajaran berhasil memperbaiki aktivitas belajar siswa dalam dua siklus.

b. Hasil penelitian menunjukkan bahwa model pembelajaran kooperatif tipe group investigation dapat meningkatkan ketuntasan pembelajaran siswa, terbukti dari hasil tes siswa ketuntasan pembelajaran siswa. Pada Siklus I rata-rata nilai tes 73,1 dengan ketuntasan pembelajaran sebesar $51,3 \%$ dan pada Siklus II ratarata nilai tes 81,7 dengan ketuntasan pembelajaran naik menjadi $85,3 \%$, sehingga berhasil memberikan ketuntasan hasil belajar secara klasikal.

\section{DAFTAR RUJUKAN}

Arikunto, Suharsimi. 2002. Prosedur Penelitian Suatu Pendekatan Praktek. Jakarta: Rineksa Cipta.

Aunurrahman. 2009. Belajar dan Pembelajaran. Bandung: Alfabeta Bandung.

Nugroho,Wahyu. 2002. Pendidikan Kewarnegaraan untuk SMP/MTs Kelas IX. Jakarta: Departemen Pendidikan.

Majid, A.. 2009. Perencanaan Pembelajaran, Bandung: Rosda.

Nur, Muhammad. 1996. Pembelajaran Koperatif. Surabaya: Universitas Negeri Surabaya.

Sardiman, A. M.. 2006. Interaksi dan Motivasi Belajar Mengajar. Jakarta: Raja Grafindo Persada.

Sukidin, dkk.. 2002. Manajemen Penelitian Tindakan Kelas. Surabaya: Insan Cendekia. 